\title{
The economic burden of protecting islands from invasive alien species
}

\author{
Thomas W Bodey", Elena Anguloº, Alok Bang ${ }^{3}$, Céline Bellard ${ }^{2}$, Jean Fantle- \\ Lepczyk $^{4}$, Bernd Lenzner ${ }^{5}$, Anna Turbelin ${ }^{2}$, Yuya Watari ${ }^{6}$, Franck Courchamp ${ }^{2}$ \\ ${ }^{1}$ School of Biological Sciences, University of Aberdeen, King's College, Aberdeen, AB24 3FX, UK \\ ${ }^{2}$ Université Paris-Saclay, CNRS, AgroParisTech, Ecologie Systématique Evolution, 91405, Orsay, \\ France \\ ${ }^{3}$ Auburn University, School of Forestry \& Wildlife Sciences, Auburn, AL, 36830, USA \\ ${ }^{4}$ Bioinvasions, Macroecology, Global Change Group, Department of Botany and Biodiversity \\ Research, University of Vienna, Vienna, Austria. \\ ${ }^{5}$ Forestry and Forest Products Research Institute, 1 Matsunosato, Tsukuba, Ibaraki 305-8687, Japan \\ *Corresponding author: thomas.bodey@abdn.ac.uk
}

\begin{abstract}
Biological invasions represent a key threat to island ecosystems, with pronounced impacts across environments and economies. The ecological impacts have received substantial focus, but the economic costs have lacked synthesis at spatial and temporal scales. Here we utilise the InvaCost database, the most comprehensive global assessment of published economic costs of invasive species, to assess reported spend by cost types and socioeconomic sectors, and to examine temporal trends in spending, across islands that differ in their political geography - nation states, overseas territories or offshore islands of continental countries. We based this assessment on 1473 unique cost entries comprising 2914 annual costs totalling almost US $\$ 100$ million in area-corrected costs between 1965-2020. We find that offshore islands of continental countries incur the greatest total and management costs. However, nation states incurred the greatest damage costs whilst substantially financing management actions, and spent an overall greater proportion of their GDP. In contrast, spending within overseas territories was significantly lower in all respects. The most impacted sector was authorities and stakeholders, demonstrating the key role of government in addressing island invasions. Temporal trends revealed continual increases in spending across all island types. This likely reflects ongoing introduction rates globally alongside an increased recognition of the importance of islands as biodiversity hotspots, and an appetite to tackle invasive species at larger and more socially complex scales. However, the high economic costs of invasions on islands substantiates the need to prevent them in order to avoid this dire threat to biodiversity and its burden on limited conservation resources.
\end{abstract}

Keywords: biodiversity; economic impact; government; InvaCost; overseas territory; socioeconomic 
bioRxiv preprint doi: https://doi.org/10.1101/2021.12.10.471372; this version posted December 13,2021 . The copyright holder for this preprint (which was not certified by peer review) is the author/funder, who has granted bioRxiv a license to display the preprint in perpetuity. It is made available under aCC-BY-NC-ND 4.0 International license. 


\section{Declarations}

\section{Funding}

See Acknowledgements:

This work was conducted following a workshop funded by the AXA Research Fund Chair of Invasion Biology and is part of the AlienScenario project funded by BiodivERsA and Belmont-Forum call 2018 on biodiversity scenarios. The authors also acknowledge the French National Research Agency (ANR-14-CE02-0021) and the BNP-Paribas Foundation Climate Initiative for funding the InvaCost project and enabled the construction of the database. TWB acknowledges funding from the European Union's Horizon 2020 research and innovation programme Marie Skłodowska-Curie fellowship (Grant No. 747120). JFL would like to thank the Auburn University School of Forestry and Wildlife Sciences for travel support to attend the InvaCost workshop. Funding for EA comes from the AXA Research Fund Chair of Invasion Biology of the University of Paris Saclay. BL acknowledges funding by the BiodivERsA-Belmont Forum Project "Alien Scenarios" (FWF project no: I 4011-B32).

\section{Conflicts of Interest N/A}

\section{Availability of Data and Material}

The analyses are based on a subset of the InvaCost Database which is available at Figshare https://doi.org/10.6084/m9.figshare.12668570 In addition, the subset used is available as Supplementary Table 1.

\section{Code Availability N/A}

\section{Authors Contributions}

TWB, CB, BL \& FC conceived the study; TWB, EA, CB, JFL, BL, AT \& YW collected additional data, with all analyses performed by TWB, EA and AT. TWB led the drafting of the manuscript, with all authors contributing critically to drafts and giving final approval of the submission for publication.

\section{Ethics Approval N/A}

\section{Consent to Participate N/A}

\section{Consent for Publication}

All authors have read the final draft and approve its submission for publication 


\section{Introduction}

Alien species, species that have been distributed beyond their natural range through human agency, are one of the driving forces of the restructuring of global and regional species distributions and compositions (Capinha et al. 2015, Russell et al. 2017; IPBES 2019). A subset of these alien species, so termed invasive alien species (IAS), can have severe, multi-faceted impacts in their novel environments (Reaser et al. 2007, Blackburn et al. 2011). For example, they can result in reductions in ecosystem integrity e.g. loss of ecosystem services such as coastal protection or inshore productivity (Orth et al. 2006, Graham et al. 2018). IAS also create declines in local economies e.g. through crop damage or reduced availability of wild food stocks (Naylor 1996, Ballew et al. 2016). Lastly, IAS can have significant impacts on human health e.g. increased costs and hospitalisations as a result of vector borne diseases (Mwebaze et al. 2010, Mavian et al. 2019).

IAS are especially problematic in island ecosystems, which are hotspots of global biodiversity (Myers et al. 2000, Mittermeier et al. 2005) with high levels of endemism and evolutionary distinctiveness (Whittaker 2007, Kier 2009). Simultaneously, islands are among the hotspots of invasion globally, with the vast majority of the world's islands and archipelagos supporting invasive species (Atkinson 1985, Bellard et al. 2016, 2017, Dawson et al. 2017, Turbelin et al. 2017). They have also experienced the greatest increases in alien species richness (van Kleunen et al. 2015), and IAS are one of the leading causes of native species extinctions on islands, and the most common threat after resource use i.e. harvesting or collection (Blackburn et al. 2004, Bellard et al. 2016, Doherty et al. 2016).

Increased recognition of the importance of island taxa to global biodiversity has resulted in substantial IAS management efforts on islands worldwide (Towns and Broome 2003, Veitch et al. 2011, Russell et al. 2017, Bellard et al. 2017, Veitch et al. 2019). In addition, small spatial scales make management measures feasible and useful to protect or restore biodiversity (Courchamp et al. 2003, Jones et al. 2016). Therefore, islands have proven to be the ideal testing ground for developing management strategies and deploying a range of techniques across invasion stages, from early detection (e.g. using environmental DNA [Takahara et al. 2013]), through population management of target IAS (e.g. using stable isotope techniques [Bodey et al. 2011]), to complete eradication (Towns and Broome 2003, Holmes et al. 2019). Such IAS management measures are typically costly and require significant resources, strategic planning and workforce capability. Hence, the geographic location of the islands in question, as well as their political situation, might be crucial in the success of IAS management efforts. Political and administrative differences, particularly when combined with their respective financial resources, may significantly affect potential or actual investment in IAS management. For example, the vast majority of small island states are considered to be developing nations, while in contrast, island overseas territories (OT) are exclusively administered by more developed nations (Dawson et al. 2014, Churchyard et al. 2014, Soubreyan et al. 2015, Vaas et al. 2017, Sieber et al. 2018). This discrepancy in the availability of financial resources may further enforce differences in ability to control IAS and protect native biodiversity when balanced against other urgent socio-economic and societal needs, particularly within small island developing states. 
An economic rationale for addressing the impacts of IAS is often necessary for justifying action (or inaction), both for governmental and non-governmental bodies. While cost-benefit analyses have frequently been conducted prior to specific management actions or prioritisation exercises (Dawson et al. 2014, Holmes et al. 2019, Carter et al. 2021), such actions tend to be conducted on a case-by-case basis, either operationally or within a specific location. Indeed, it has been frequently argued that prevention of IAS impacts is less cost intensive than post-invasion adaptation and mitigation measures (Leung et al. 2002, Timmins and Braithwaite 2002; Russell et al. 2015). Beyond island-, or even country-specific contexts, we are currently lacking a global synthesis of economic costs of IAS on islands (Reaser et al. 2007). This is concerning as such a synthesis helps to identify knowledge and/or management gaps both locally and internationally, and highlights actions that can produce synergies across sectors. Such win-win scenarios are particularly important for nations with limited financial resources.

Using the recently developed 'InvaCost' database (Diagne et al. 2020), we collated reported costs of IAS on islands worldwide. Specifically, we compared reported costs of management (control, biosecurity, etc.) and damages (agricultural losses, etc.) associated with IAS, across socioeconomic sectors among islands differing in political geography (nation states, overseas territories or offshore islands of continental countries). We also compared temporal trends in spending across these different island categories. We hypothesised that i) the spending ratio between control/management and damage mitigation will be equivalent across the three island categories. That is, the economic impacts of IAS are felt, and responded to, similarly on all islands. However, as a result of their ties to larger and often financially wealthier states ii) overseas territories and offshore islands of continental countries would have proportionately greater expenditures, particularly as these locations are frequently managed for their contribution to biodiversity. Finally, in light of the ongoing increase in, and recognition of IAS impacts, we hypothesized that iii) all islands would experience increasing expenditures over time. 


\section{Methods}

Invacost dataset

We used the InvaCost_3.0 database (Diagne et al. 2020), a publicly available living repository which compiles the reported monetary impacts of invasive species globally (https://doi.org/10.6084/m9.figshare.12668570). Diagne et al. (2020) developed InvaCost via standardized literature searches (via the Web of Science platform and the Google Scholar and Google search engines), coupled with opportunistic, targeted searches where data gaps were identified. Analogous searches were conducted in more than 10 non-English languages in e.g. French, Spanish, Chinese and Japanese (Angulo et al. 2021). Costs were extracted from the found sources and standardised to a common currency (2017 US dollars) based on annual average market exchange rate and inflation factors.

\section{Data Processing}

\section{a) Economic costs and island characteristics}

Within the InvaCost database, costs were categorized by method reliability and implementation type, as well as by cost type and impacted sector, as explained below. To derive our islands database (Fig 1, Table S1), we screened the full database by the following available metadata columns:

i) First, to derive all island-associated costs, the 'Official_country' column was used to select all island nation states, and then column 'Location' was used to include all costs associated with offshore islands of continental nations, such as the Galapagos (offshore islands of Ecuador) or Reunion (OT of France).

ii) Next, to provide the most robust, conservative estimates of the costs of island invasions, we considered only highly reliable (entries assigned with high in the 'Method reliability' column) and observed (entries assigned with observed in the 'Implementation' column) costs in our estimations, thus excluding entries that were not from peer-reviewed literature or official reports (e.g., government documents), or were otherwise not reproducible (labeled as low reliability), as well as those that were expected but not empirically observed (labeled as potential, Diagne et al. 2020). However, we retained studies where costs observed at a small scale within an island were extrapolated to larger areas of the same location. We thus consider this approach, which results in 1,473 unique cost entries, to provide minimum but robust estimates of the economic impacts of IAS on islands. There is no guarantee that inclusion of low reliability data or potential costs would produce a comprehensive estimate, as many undocumented costs also undoubtedly occur (Diagne et al. 2020, 2021).

Then, in order to allow for accurate comparisons, costs were standardised to costs in 2017 US \$ per km² using information provided by the 'Spatial_scale' column on the unit of measurement, when necessary returning to the primary source for clarification. Where no smaller unit of measurement was given, the cost was assumed to apply across the entire island.

Finally, we used the three categories of cost types from the 'Type_of_cost_merged' column: Management (e.g. any form of population control, biosecurity, eradication effort), Damage (e.g. repairs to infrastructure, human health impacts) and Mixed 
(including cost types from both previous categories and the very small quantity of unspecified costs $[<0.0001 \%]$ ). The 'Impacted_sector' column was combined into broader categories of socioeconomic impact, namely: Authorities-Stakeholders, Primary Industries (agriculture, forestry, fisheries etc), Health and Social Welfare, Environment and Mixed (including costs across multiple sectors).

\section{b) Island characteristics}

Costs were compared across a common metric through currency standardisation and scaling to a unit of cost $\mathrm{km}^{-2}$ (see above). We then added two additional classifiers: i) 'Island Type' to divide islands across three distinct political geographic categories: island Nation States (NSs, this includes all sovereign island nations present including small island developing states); offshore Islands of Continental Countries (ICCs); and Overseas Territories (OTs), and ii) an income classifier using the World Bank's gross national income (GNI) assessment (four categories: lower, lower middle, upper middle, upper income country [World Bank Development Indicators]). We also added the most recent 10-year average of the relevant country's GDP (i.e. the NS itself, or the continental country or ultimate administrative country of the island or OT in question).

\section{c) Estimating Total Costs and Temporal Trends}

Finally, in order to assess the full economic impact of cost entries, we annualized the cost values to consider the temporal frame in which they occurred, because the duration of reported costs could vary from a few months to years. Thus, we expanded rows within the database that corresponded to costs spanning multiple years in order that costs can be comparable and provide an accurate assessment of the economic costs of IAS through time. These multi-year costs were expanded using the 'invacost' package in R v4.0.3 (R Core Team 2020, Leroy et al. 2020) based on the 'Probable_starting_year_adjusted' and

'Probable_ending_year_adjusted' columns. When this information was unclear within the primary source ( $n=18$ entries with no clear starting year), we conservatively considered that costs occurred in only one year using the year determined from the source as the relevant year in question. This resulted in an expanded dataset of 2,914 annual costs covering the years 1965 - 2020. However, for the analysis of temporal trends we excluded costs that occurred before $1965(n=3)$ due to the small sample size, and also costs after $2017(n=706)$, due to publication lags resulting in substantially incomplete data for more recent years (median publication lag, defined as the difference between publication and impact years of the study, was 3 years). Temporal trends were assessed through implementing the summarizeCosts function of the 'invacost' package (Leroy et al. 2020), and were examined independently for total reported costs across all islands, across each island type separately, and for exclusive management and damage costs. 


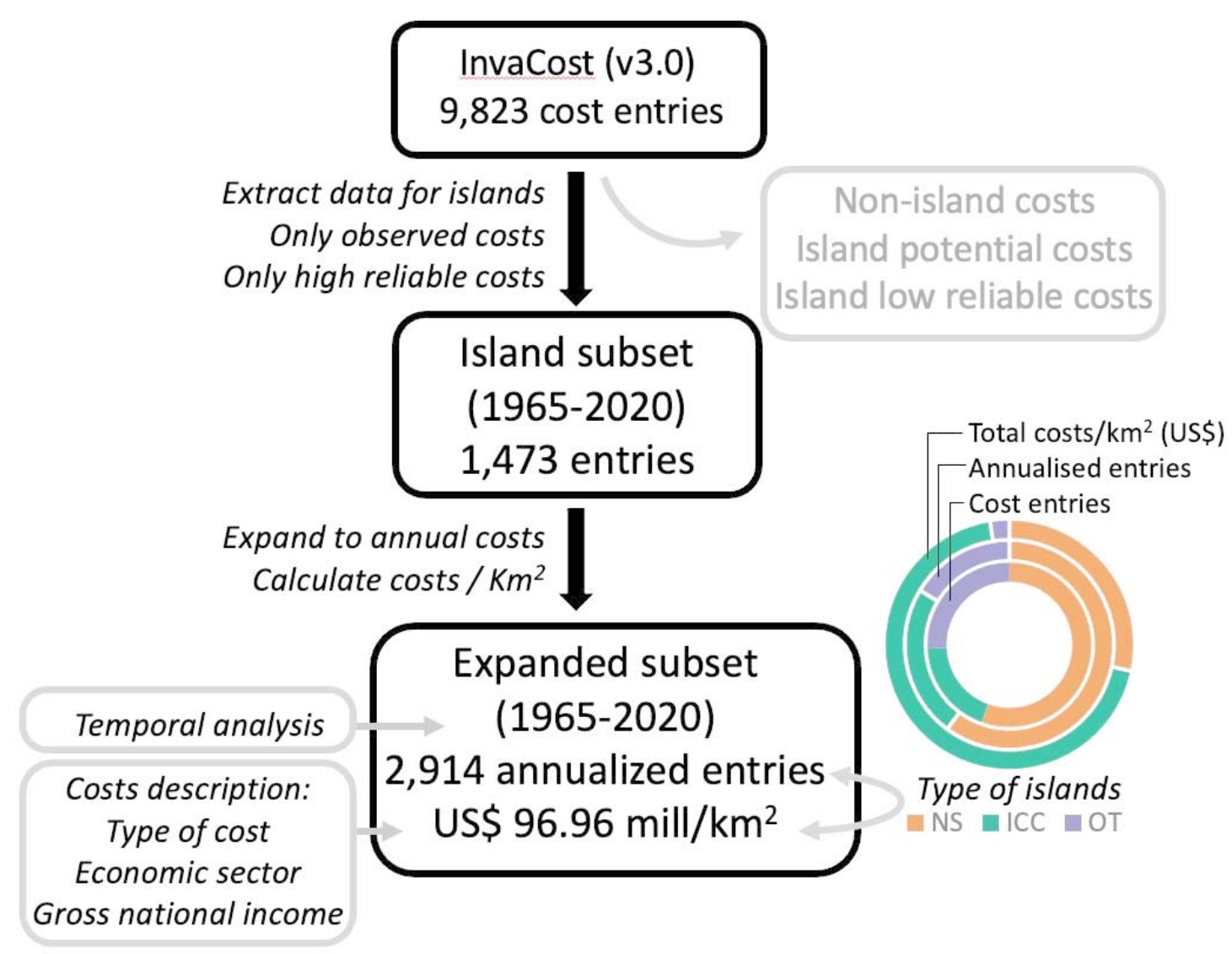

Fig 1. Workflow showing the extraction and filtering processes to determine the reported economic costs of invasive alien species occurring on islands. The graph depicts the proportion of entries, the proportion of annualised costs records and proportion of total costs in US\$ millions $\mathrm{km}^{-2}$ spent by island type (ICC: Island of Continental Country, OT Overseas Territory and NS: Nation State). 


\section{Results}

The complete islands dataset consisted of 1,473 unique cost entries, resulting in 2,914 annualised costs spanning the years $1965-2020$ that summed to US $\$ 96.96$ million in $\mathrm{km}^{-2}$ corrected costs. The majority of cost entries were from NSs, but the greatest economic costs were reported from ICCs (Fig 2, Table S2). Geographically, spending on islands was dominated by the Pacific region ( $45 \%$ of costs including both NSs and islands with political ties to Oceania, Europe, South and North America) and Europe (41\% of costs, Fig 2).

Across all islands, the large majority of costs $(61 \%)$ were classified as exclusively management related, with exclusive damage costs comprising a much smaller proportion (3\%) of the total (Fig 3a). However, the breakdown of this spending was not equivalent across island types, with ICCs spending the most on exclusive management costs and the most in total. NSs spent nearly as much on management, and incurred the majority of damage costs, although a substantial proportion of ICC costs were classified as mixed, and so contained some unknown proportion of damage within them (Fig 3a, Table S3). Total reported spending in OTs was an order of magnitude lower for management, and almost two orders of magnitude lower for damage than in the other island types. While the ratio of management to damage spending was broadly equivalent between ICCs and OTs, this decreased in NSs as a result of the higher damage spend (Table S3). However, as a proportion of GDP, there were large differences between each island type, with NSs spending the greatest fraction of their available income on IAS costs, an order of magnitude higher than the proportion of GDP spent in ICCs, and two orders of magnitude higher than the OT's ultimate administrative country's GDP (Fig 3b, S1, Table S3).

Considering costs by socioeconomic sectors revealed dominant spending incurred by the Authorities-Stakeholders category (77\% of annualised costs), with lesser costs attributed to the Environment (12\%) and Primary Industries (5\% - of which $>90 \%$ comprised unspecified agricultural-forestry costs) categories (Fig 3c). Cost by sector was also not evenly spread across island types, with almost all Primary Industry costs incurred by NSs, whereas costs to Authorities-Stakeholders and the Environment dominated on ICCs. In terms of principal species incurring costs (for this we considered only costs that were clearly assigned to single species) there was almost no overlap among island types or between the principal species incurring management or damage costs (Fig 4). NS and ICC management spending was dominated by mammals and flowering plants, whereas OT management spending was dominated by insect related costs. Damage spending, although a much smaller proportion of the total, was also spread more diversely across classes in all island types (Fig 4). When compared by gross national income, the data was dominated by high and upper middle income category countries, with only a single cost estimate for a low income country, and with low and lower middle income countries representing only $0.2 \%$ of all reported annualised costs (Table S4).

When examining trends in spending through time, when all islands are considered together, there is an increasing trend in total reported costs through each decade from 1960 to 2017 apart from the 1990s, although step changes over this period are clearly evident (Fig 5). This trend is mirrored, where data is available, for all island 
types considered separately, with NSs exhibiting the decline in costs in the 1990s, but trends for both ICCs and OTs continually increasing. It is also true for both management and damage costs when considered separately, but with management costs consistently at least an order of magnitude greater (Fig 5).

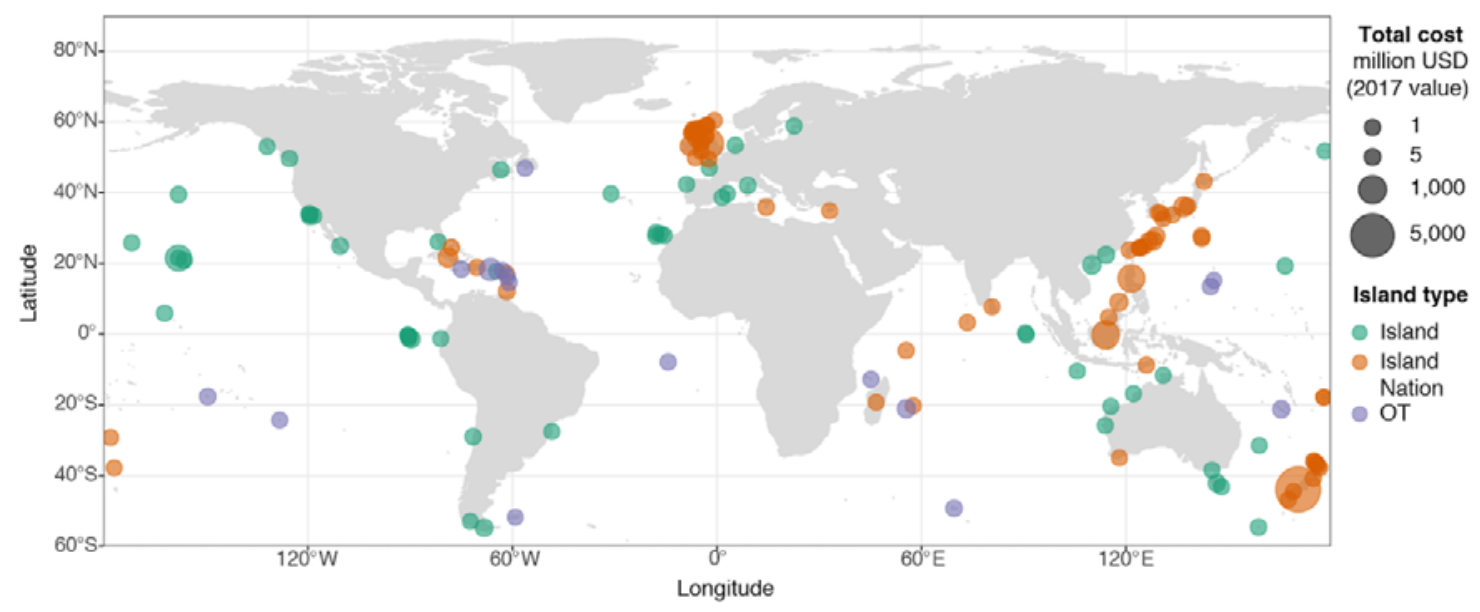

Fig 2. Global locations and magnitudes of reported economic costs of invasive alien species on islands. All costs are in 2017 US $\$ \mathrm{~km}^{-2}$ 


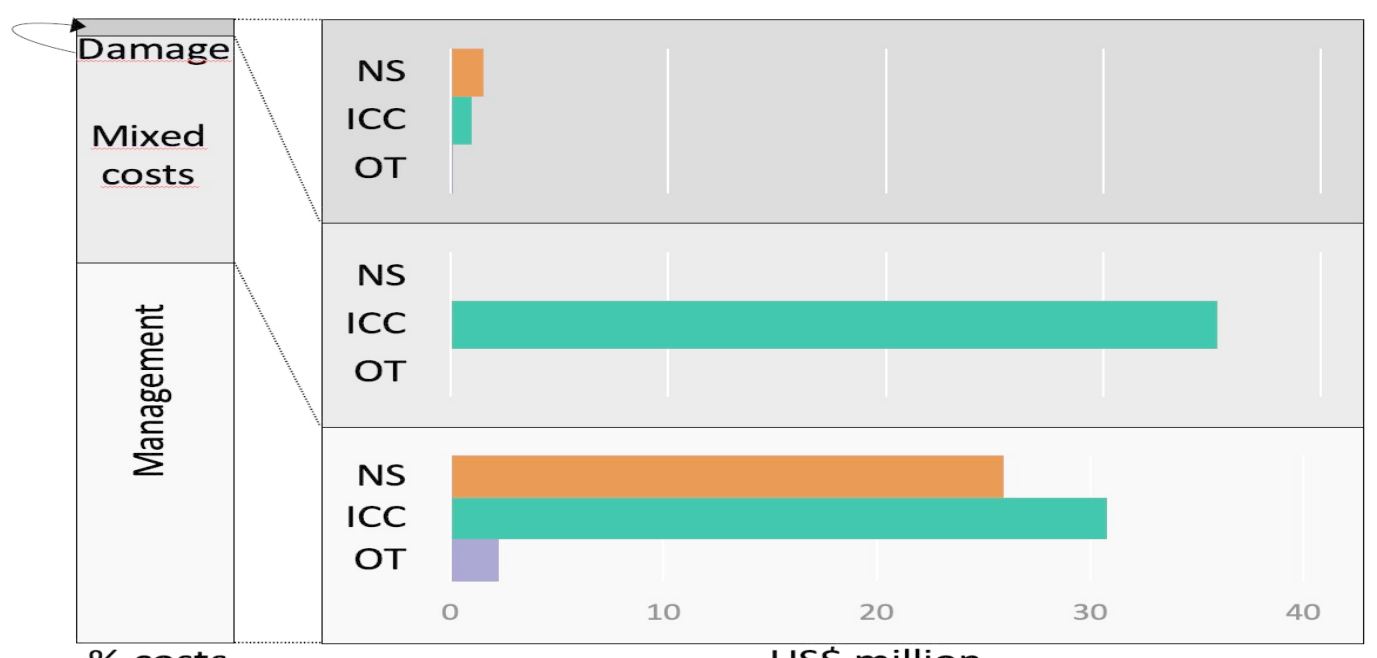

$\%$ costs

US\$ million

b

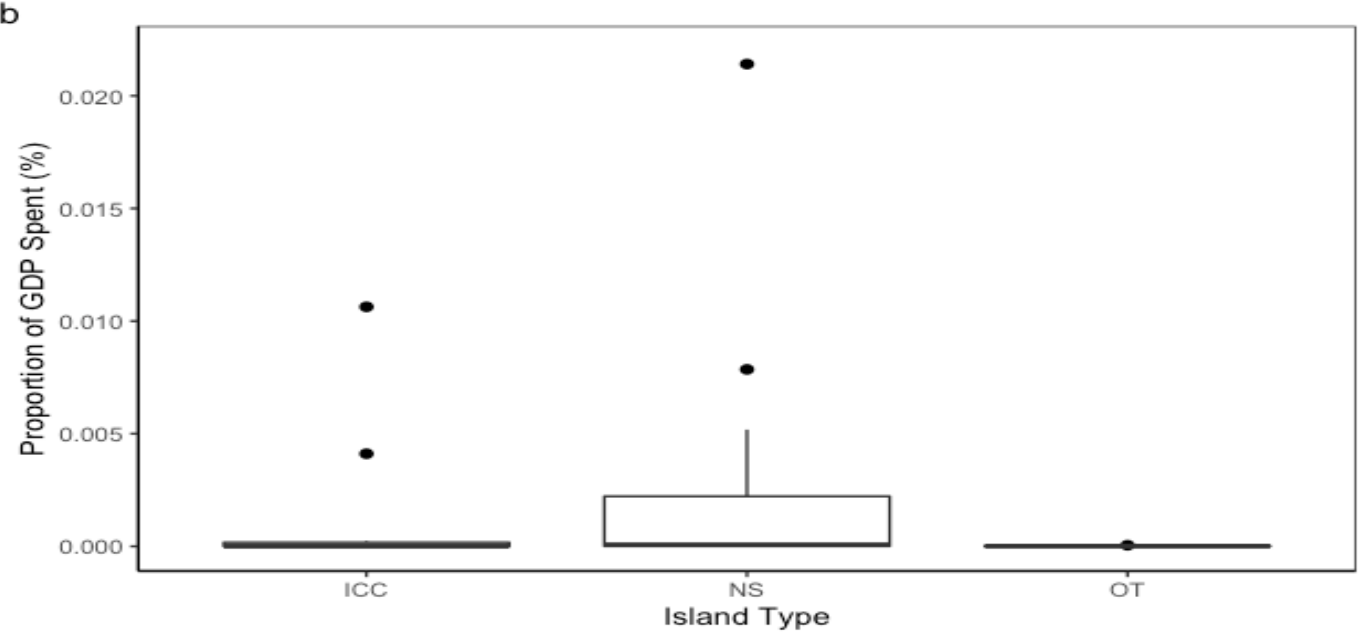

C
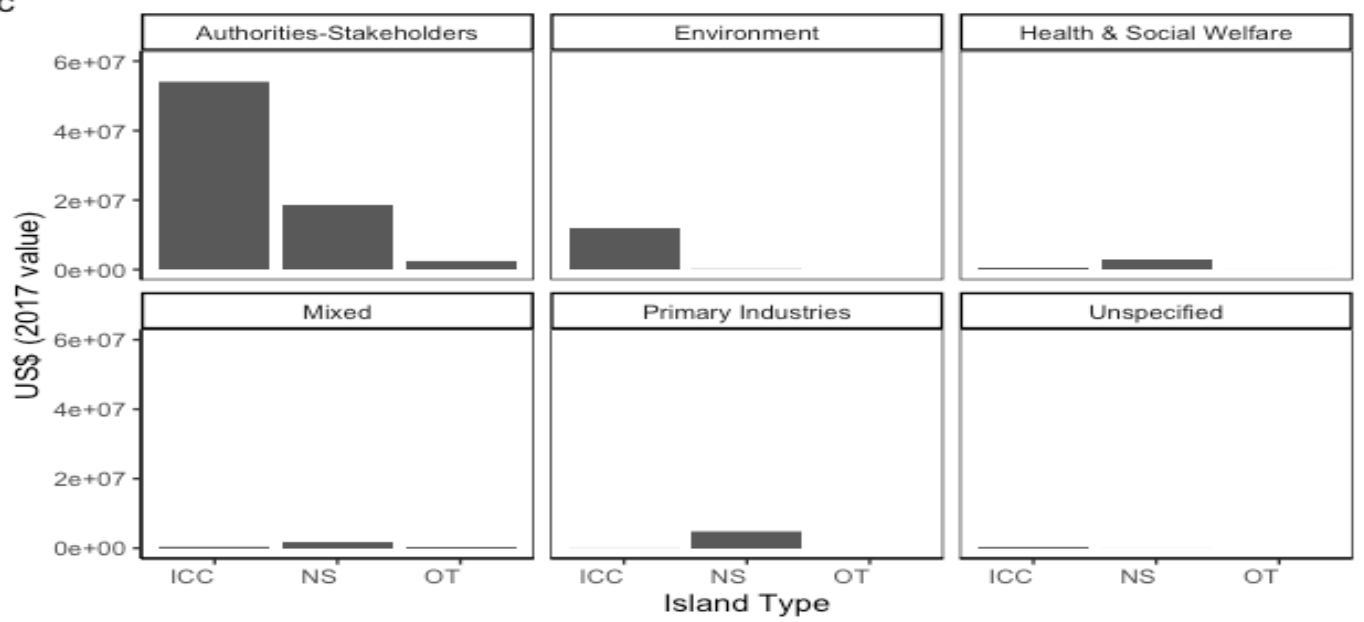

Fig 3. a) Distribution of costs by proportion across main cost types and by US $\$$ millions $\mathrm{km}^{-2}$ across island categories $\mathrm{b}$ ) Spend as a proportion of GDP by island type c) Distribution of costs across principal socio-economic sectors. (NS - Nation State, ICC - Island of Continental Country, OT -Overseas Territory) 

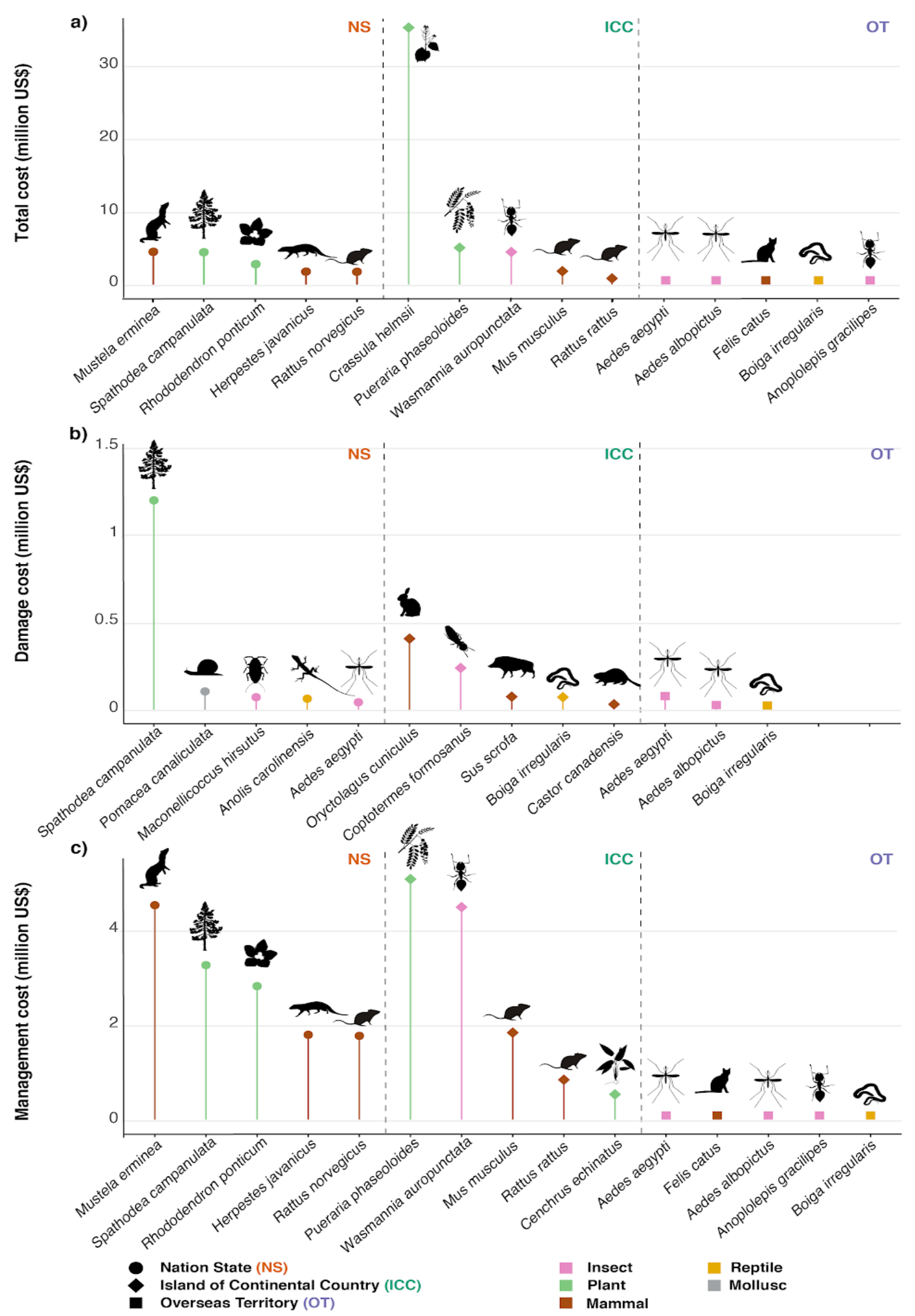

Fig 4. Top five most costly species by island type for (a) all costs, (b) exclusive damage costs and (c) exclusive management costs. All costs are in US\$ $\mathrm{km}^{-2}$. There was almost no overlap between species across different island types: NS (circles), ICC (diamonds), OT (squares). Note only three species had exclusive damage costs within OTs. 
bioRxiv preprint doi: https://doi.org/10.1101/2021.12.10.471372; this version posted December 13, 2021. The copyright holder for this preprint (which was not certified by peer review) is the author/funder, who has granted bioRxiv a license to display the preprint in perpetuity. It is made available under aCC-BY-NC-ND 4.0 International license.
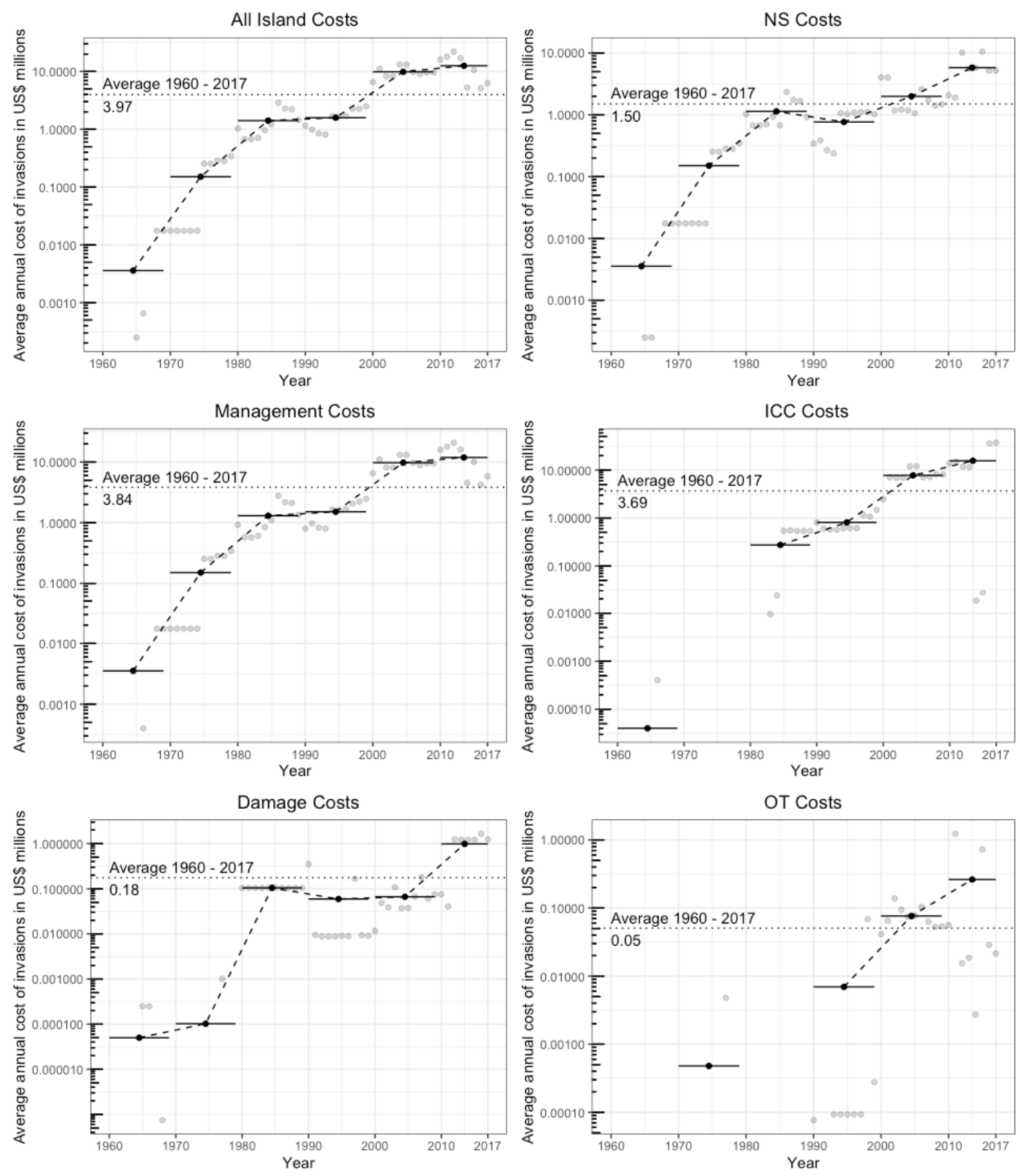

Fig 5. Temporal trends in reported total spending on the economic impacts of IAS across different type of costs and island types. Note the differing and logarithmic scales of the $y$ axes when comparing expenditure. 


\section{Discussion}

We found that reported spend in insular systems to address the economic impacts of IAS comprised almost US $\$ 100$ million in area-corrected costs over the past 55 years, but that there was significant variation in the types of costs across islands, particularly in respect to their political geography. Our first hypothesis - that the spending ratio between control/management and damage mitigation would be equivalent across island categories - was not supported by our results. Instead, reported ratios were lowest for Nation States (NS), with management spend far higher compared to damage in other island types. Our second hypothesis, that Overseas Territories (OT) and Islands of Continental Countries (ICC) would have greater total expenditure as a result of their connections to wealthier countries, was, surprisingly, similarly not fully supported. While ICCs did incur the greatest costs in total and over time (Figs 2, 3), this trend was not mirrored in OTs, where spending substantially lagged behind both ICCs and NSs. However, in agreement with our third hypothesis, spending across all islands combined, or across any island types considered separately, has continued to increase through time, potentially reflecting both the continuing emergence of alien species and recognition of an increasing ability to address these issues.

\section{Patterns of spending}

Management costs dominated spending, comprising approximately two thirds of all reported expenditure on islands. However, this proportion is likely substantially higher given the large number of mixed management-damage costs reported within ICCs (Fig 2). The large proportion of spending devoted to management is in contrast to most individual countries or broader regions where costs due to IAS damage consistently outstrip management expenditure (Haubrock et al. 2021, Diagne et al. 2021 but see Bodey et al. 2021 and Watari et al. 2021). Geographically, spending was greatest in the Pacific region and western Europe, with a notable lack of reported costs from island-rich, biodiversity hotspots such as the Caribbean, SE Asia and the western Indian Ocean (Mittermeier et al. 2005). NSs incurred the greatest costs for damages, with lower to negligible figures reported by ICCs and OTs respectively. It is notable that NSs spent a far greater (although still extremely small) proportion of their GDP on economic costs from IAS. This may reflect the greater impact of IAS on NS economies where, for example, damage to crops or other primary industries directly impacts the country's capacity to feed itself or increase its export capacity (Reaser et al. 2007, Mwebaze et al. 2010). Indeed, reported costs to primary industries occur almost exclusively within NSs, where there may be a greater recognition of the need to protect finite and limited resources. Furthermore, NSs may also have an increased recognition of the value of their unique biodiversity for generating income from natural capital or ecotourism (Fotiou et al. 2002, Dolins et al. 2010, Ballesteros-Meija et al. 2021). Similarly, the limited damage costs reported in ICCs and OTs likely reflect their relatively small contribution to the governing country's overall economy (industry or infrastructure). This, coupled with small proportions of national populations resident in ICCs and OTs and their spatial isolation, and thus limited electoral influence, may influence the extent of spending reported, particularly for damage costs, for these island types. 
In contrast, costs on ICCs were substantially devoted to management, with more than a 30-fold difference compared to their damage costs. ICCs are much more likely to comprise uninhabited locations where significant recordable economic damages are far less likely, particularly to socioeconomic sectors such as primary industries or human health. Rather, damage costs in these locations may reflect losses to biodiversity and ecosystem function, but placing monetary values on such losses is complex, particularly where human livelihoods are negligibly affected by impacts to ecosystem services (Nunes et al. 2001, Kallis et al. 2013, Roberts et al. 2018). On the other hand, ICCs may receive significant management spending on IAS control and eradication as they are likely targets for ecological restoration, particularly through the removal of invasive terrestrial species, following early conservation models established in New Zealand (Towns and Broome 2003, Jones et al. 2016, Veitch et al. 2011, 2019). Under this model, these islands can be used as 'arks' and either sustain relict and subsequently recovering populations, or receive translocations, of highly endangered naïve island endemics that may receive exceptional financial support due to their greater extinction risk (Jones et al. 1995, Carthey \& Banks 2014, Russell et al. 2015). This is demonstrated by the dominance of reported costs from ICCs with highly successful IAS eradication campaigns including: Macquarie Island, Australia (Helmstedt et al. 2016), the California Channel Islands, USA (Parkes et al. 2010), the Galapagos, Ecuador (Carrion et al. 2011) and a large number of islets and islands around Mexico (Samaniego-Herrera et al. 2018). In addition, many uninhabited offshore islands are also protected areas of varying legislative status, which may increase the likelihood of IAS management in these locales. Notably, the socioeconomic sector incurring the greatest proportion of reported costs across all islands, but particularly incurred by ICCs, is that of authorities and other stakeholders, evidence that these management costs tend to fall to governmental organizations and conservation NGOs. However, it was also apparent that there was almost no consistency in the species generating the majority of either management or damage costs across island types. While there is the potential for this to reflect a lack of uniformity in the reporting of costs incurred by specific species, and no doubt also reflects some regional, latitudinal or societal differences, it also strongly suggests there is a need for greater information sharing to synergise experience across locales considering the fact that many islands support similar IAS (McKinney and Lockwood 1999, Simberloff et al. 2013).

\section{Under-reported or underfunded?}

Regardless of the type of cost, it is clear that spending in OTs is substantially lower than on other islands, and this is seen not just in absolute cash terms, but exceedingly so in the proportion of the ultimate administrative countries' GDP (Table 2). As these costs are corrected for area, this is not simply a reflection of the smaller landmass OTs occupy globally. Instead, it appears that countries maintaining OTs either do not record, or do not invest in, IAS management or damage mitigation at any significant scale, as there is no evidence to suggest that IAS presence is decreasing in these locations contrary to the global trend (Dawson et al. 2017, Seebens et al. 2017). Indeed, the effort expended on recording IAS costs in OTs appears to vary substantially by location. For example, New Caledonia represents the highest number of IAS cost entries, though not the highest spending, within the French départements, with Réunion also recording substantial numbers of IAS and 
associated costs (Renault et al. 2021). However, simultaneously, there is little data on IAS presence or costs for other French OTs including Mayotte, Martinique and French Guiana (Turbellin et al. 2017, Renault et al. 2021). In contrast, Cuthbert et al. (2021) do not include IAS costs from OTs in an examination of the impacts of IAS to the UK economy, potentially as a result of limited reporting reflecting a general pattern of oversight and undervaluing of these locations (Churchyard et al. 2014). Most OTs represent small islands with limited internal resources comparable to many small island nations amongst the NSs, and without substantial support from the ultimate governing country, they are likely to struggle to conserve the biodiversity they support (Churchyard et al. 2014, Key 2017, Vaas et al. 2017). While the InvaCost database collected data on monetary values, and so may fail to capture some costs of biodiversity or cultural losses, for example the ecosystem functions of extinct island endemics (Zavaleta et al. 2001, Wood et al. 2017), it is unlikely that the data collection process missed so much spending in OTs that it would then be equivalent to other island types, especially when such values may also go unrecorded elsewhere.

Our work also highlights the almost complete lack of cost records from developing nations, with $>99 \%$ of all reported island costs occurring in countries classified by the World Bank as higher or upper middle income countries. Given that several of the largely or completely absent countries represent mega-diverse biological hotspots (Mittermeier et al. 2005), this highlights a pressing research or assessment need or, minimally, an urgent effort to increase the ability to produce and disseminate publications (Wallace et al. 2020). The absence of reported costs may reflect a true knowledge gap that, in turn, may reflect a difference in perceived priorities between countries that have pressing needs around sectors such as human health and education. It may also reflect a limited number of studies due to poorer funding opportunities as compared to their richer counterparts. In either event, there is an urgent need to improve our understanding of the costs of IAS in these locations due to the likely severe negative impacts invasive species have on a range of indicators, including health, productivity, happiness, child poverty levels, and declines in ecosystem services (United Nations 2017) as well as biodiversity (Simberloff et al. 2013).

\section{Temporal trends}

Given the importance of islands to global diversity, temporal trends in spending on management exhibit an encouraging trend across all islands where, regardless of political geography, average decadal spending has increased almost uniformly between 1960 and 2017. In addition, this expenditure on management has consistently been at least an order of magnitude greater than that spent on damage (Fig 3). While publication delays mean that estimates for the most recent years are necessarily an underestimate, this trend is certain to continue for at least the 2010s, and is in stark contrast to the repartition of reported spending on IAS globally (Diagne et al. 2020). While the specific reasons for continued spending may differ across islands of differing political geography, this potentially reflects ongoing increases in rates of introductions (Seebens et al. 2017, Lenzner et al. 2020), allied to increased recognition of the importance of islands as biodiversity hotspots (Mittermeier et al. 2005) and an increasing appetite to tackle IAS at larger and more socially complex scales (Oppel et al. 2011, Russell et al. 2015, Veitch et al. 2019, 
Carter et al. 2021). Such efforts have the potential to lead to substantial conservation gains (Jones et al. 2016, Holmes et al. 2019). However, translating approaches from uninhabited to inhabited islands is challenging, and the logistical difficulties, social challenges and necessarily increased costs associated with such endeavours may constrain the capacity or willingness of governments to commit to such endeavours given the current higher risk of failure (Oppel et al. 2011, Russell et al. 2015, Harper et al. 2020).

\section{Conclusion}

Using the most comprehensive available data on the economic impacts of IAS on islands, we demonstrated that the political geography of an island is central to the type and quantity of expenditure and/or the likelihood of reporting costs. Nation States were more likely to report losses due to damage caused by IAS, likely reflecting the more significant impact such losses make on their overall economies, but also revealing probable knowledge gaps as to the extent of many socioeconomic impacts of IAS across all locations (cf Crystal-Ornelas and Lockwood 2020). There is also a clear disparity in reporting of costs from developing nations and, despite islands from all categories supporting unique biodiversity, spending was especially low in Overseas Territories. Given the importance of Overseas Territories to total country biodiversity, a greater focus of attention on the impacts of IAS in these locations would ensure European countries, in particular, made substantial progress towards the achievement of Aichi Biodiversity targets under the Convention on Biological Diversity (CBD 2011). Such an approach would benefit all islands given the strong overlap between the Aichi biodiversity targets and sustainable development goals (Schultz et al. 2016, UN 2017). Nevertheless, the predominance of spending on management approaches (incorporating all stages from biosecurity through to long-term control/eradication), and the continuing increase in this spend over time across all islands, suggests that there continues to be the potential to make substantial conservation and development gains in insular ecosystems. In particular, the high economic burden imposed by biological invasions on islands adds to the strong evidence that prevention rather than management will better protect insular biodiversity.

\section{Acknowledgements}

This work was conducted following a workshop funded by the AXA Research Fund Chair of Invasion Biology and is part of the AlienScenario project funded by BiodivERsA and Belmont-Forum call 2018 on biodiversity scenarios. The authors also acknowledge the French National Research Agency (ANR-14-CE02-0021) and the BNP-Paribas Foundation Climate Initiative for funding the InvaCost project and enabled the construction of the database. TWB acknowledges funding from the European Union's Horizon 2020 research and innovation programme Marie Skłodowska-Curie fellowship (Grant No. 747120). JFL would like to thank the Auburn University School of Forestry and Wildlife Sciences for travel support to attend the InvaCost workshop. Funding for EA comes from the AXA Research Fund Chair of Invasion Biology of the University of Paris Saclay. BL acknowledges funding by the BiodivERsA-Belmont Forum Project "Alien Scenarios" (FWF project no: I 4011-B32). 


\section{References}

Atkinson IAE (1985). 'The spread of commensal species of Rattus to oceanic islands and their effects on island avifaunas'. In: P.J. Moors (ed.) Conservation of Island Birds. pp. 3581. Cambridge, United Kingdom: International Council for Bird Preservation.

Angulo E, Diagne C, Ballesteros-Mejia L, Adamjy T, Ahmed DA, Akulov E, Banerjee AK, Capinha C, Dia CAKM, Dobigny G, Duboscq-Carra VG, Golivets M, Haubrock PJ, Heringer G, Kirichenko N, Kourantidou M, Liu C, Nuñez MA, Renault D, Roiz D, Taheri A, Verbrugge L, Watari Y, Xiong W, Courchamp F Non-English languages enrich scientific knowledge: the example of economic costs of biological invasions. Science of the Total Environment. In Press.

Ballesteros-Mejia L, Angulo E, Diagne C, Cooke B, Nuñez MA, Duboscq- Carra VG, Courchamp F Economic costs of biological invasions in Ecuador: the importance of the Galapagos Islands. NeoBiota. In Press.

Ballew NG, Bacheler NM, Kellison GT, Schueller AM (2016). Invasive lionfish reduce native fish abundance on a regional scale. Sci Rep. 6:1-7. doi: 10.1038/srep32169

Bellard C, Genovesi P, Jeschke J (2016) Global patterns in threats to vertebrates by biological invasions. Proc Roy Soc B Biol Sci 283: 20152454.

doi:https://doi.org/10.1098/rspb.2015.2454

Bellard C, Rysman J-F, Leroy B, Claud C, Mace GM (2017) A global picture of biological invasion threat on islands. Nature Ecol Evol 1:1862-1869. doi:10.1038/s41559-017-0365-6

Blackburn TM, Cassey P, Duncan RP, Evans KL, Gaston KJ (2004) Avian extinction and mammalian introductions on oceanic islands. Science 305:1955-1958.

https://doi.org/10.1126/science. 1101617

Blackburn TM, Pysek P, Bacher S, Carlton JT, Duncan RP, Jarosik V, Wilson JRU, Richardson DM (2011) A proposed unified framework for biological invasions. Trends Ecol Evol 26:333-9.

Bodey, TW, Bearhop, S and McDonald RA (2011) Invasions and stable isotope analysis informing ecology and management. Island invasives: eradication and management Gland, Switzerland: IUCN, 148-151.

Bodey TW, Cater ZT, Haubrock PJ, Cuthbery RN, Welsh MJ, Diagne C and Courchamp F. Biological invasions in New Zealand - towards a comprehensive economic cost synthesis. NeoBiota. In Press

Capinha C, EssI F, Seebens H, Moser D and Pereira HM (2015) The dispersal of alien species redefines biogeography in the Anthropocene. Science 348:1248-1251.

Carrion V, Donlan CJ, Campbell KJ, Lavoie C, Cruz F (2011) Archipelago-Wide Island Restoration in the Galápagos Islands: Reducing Costs of Invasive Mammal Eradication Programs and Reinvasion Risk. PLoS ONE 6(5): e18835.

https://doi.org/10.1371/journal.pone.0018835

Carter ZC, Lumley T, Bodey TW, Russell JC (2021) The clock is ticking: temporally prioritizing eradications on islands. Global Change Biology https://doi.org/10.1111/gcb.15502 
Carthey AJR, Banks P (2014) Naïveté in novel ecological interactions: lessons from theory and experimental evidence. Biol Rev 89:932-949.

Churchyard T, Eaton MA, Havery S, Hall J, Millett J, Farr A, Cuthbert RJ, Stringer C, Vickery JA (2014) The biodiversity of the United Kingdom's Overseas Territories: A stock take of species occurrence and assessment of key knowledge gaps. Biodivers Cons 25:16771694.

CBD (Convention on Biological Diversity) (2011) Strategic Plan for Biodiversity 2011-2020, Including Aichi Biodiversity Targets. https://www.cbd.int/sp/

Courchamp, F, Michel Pascal \& Jean-Louis Chapuis (2003) Mammal invaders on islands, impact, control and control impact. Biol Rev 78:347-383.

Crystal-Ornelas R \& Lockwood JL (2020) The 'known unknowns' of invasive species impact measurement. Biol Inv 22:1513-1525

Cuthbert RN, Bartlett AC, Turbellin A, Haubrock PJ, Diagne C, Pattison Z, Courchamp F, Catford JA Economic costs of biological invasions in the United Kingdom. NeoBiota. In Press

Dawson J, Oppel S, Cuthbert RJ, Holmes N, Bird JP, Butchart SHM, Spatz DR, Tershy B (2014) Prioritizing islands for the eradication of invasive vertebrates in the United Kingdom overseas territories. Cons Biol 29:143-153.

Dawson W, Moser D, van Kleunen M, Kreft H, Pergl J, Pysek P, Weigelt P, Winter M, Lenzner B, Blackburn TM, Dyer EE, Cassey P, Scrivens SL, Economo EP, Guenard B, Capinha C, Seebens H, Garcia-Diaz P, Nentwig W, Garcia-Berthou E, Casal C, Mandrak NE, Fuller P, Meyer C, EssI F (2017) Global hotspots and correlates of alien species richness across taxonomic groups. Nat Ecol Evol 1:0186. https://doi.org/10.1038/s41559$\underline{017-0186}$

Diagne C, Leroy B, Gozlan RE, Vaissière AC, Assailly C, Nuninger L, Roiz D, Jourdain F, Jarić I, Courchamp F (2020) InvaCost, a public database of the economic costs of biological invasions worldwide. Scientific Data 7:277. doi:https://doi.org/10.1038/s41597-020-00586-z

Doherty TS, Glenc AS, Nimmod DG, Ritchiea EG, Dickman CR (2016) Invasive predators and global biodiversity loss. PNAS 113:11261-11265.

Dolins FL, Jolly, A, Rasamimanana, H, Ratsimbazafy, J, Feistner, ATC and Ravoavy, F (2010) Conservation education in Madagascar: three case studies in the biologically diverse island-continent. Am J Primatology 72:391-406.

Fotiou S, Buhalis D, Vereczi G (2002) Sustainable development of ecotourism in small islands developing states (SIDS) and other small islands. Tourism and Hospitality Research 4:79-88.

Graham NAJ, Wilson SK, Carr P, Hoey AS, Jennings S, MacNeil MA (2018) Seabirds enhance coral reef productivity and functioning in the absence of invasive rats. Nature 559:250-253. doi: 10.1038/s41586-018-0202-3

Harper GA, Pahor S, Birch D (2020) The Lord Howe Island rodent eradication: lessons learnt from an inhabited island. Proceedings 29th Vertebrate Pest Conference, 31. 
Haubrock PJ, Turbelin AJ, Cuthbert RN, Novoa A, Angulo E, Ballesteros-Mejia L, Bodey TW, Capinha C, Diagne C, EssI F, Golivets M, Kirichenko N, Kourantidou M, Leroy B, Renault D, Taylor N, Verbrugge L, Courchamp F. Economic costs of invasive alien species across Europe. NeoBiota. In Press

Helmstadt KJ, Shaw JS, Bode M, Terauds A, Springer K, Robinson SA, Possingham HP (2016) Prioritizing eradication actions on islands: it's not all or nothing. J Appl Ecol 53:733741.

Holmes N, Spatz DR, Oppel S, Tershy B, Croll DA, Keitt B, . . Bond AL (2019) Globally important islands where eradicating invasive mammals will benefit highly threatened vertebrates. PLoS ONE 14: e0212128 https://doi.org/10.1371/journal.pone.0212128

IPBES (2019): Summary for policymakers of the global assessment report on biodiversity and ecosystem services of the Intergovernmental Science-Policy Platform on Biodiversity and Ecosystem Services. Díaz S, Settele J, Brondízio ES, Ngo HT, Guèze M, Agard J, Arneth A, Balvanera P, Brauman KA, Butchart SHM, Chan KMA, Garibaldi LA, Ichii K, Liu J, Subramanian SM, Midgley GF, Miloslavich P, Molnár Z, Obura D, Pfaff A, Polasky S, Purvis A, Razzaque J, Reyers B, Chowdhury RR, Shin YJ, Visseren-Hamakers IJ, Willis KJ, Zayas CN (eds.). IPBES secretariat, Bonn, Germany. 56 pages.

https://doi.org/10.5281/zenodo.3553579

Jones CG, Heck W, Lewis RE, Mungroo Y, Slade G, Cade T (1995) The restoration of the Mauritius Kestrel Falco punctatus population. Ibis 137:S173-S180.

Jones HP, Holmes ND, Butchart SHM, Tershy BR, Kappes PJ, Corkery I, . . Croll DA (2016) Invasive mammal eradication on islands results in substantial conservation gains.

PNAS 113:4033-4038.https://doi.org/10.1073/pnas.1521179113

Kallis G, Gomez-Baggethen E, Zografos C (2013) To value or not to value? That is not the question. Ecol Econ 94:97-105

Key J (2017). Tackling Invasive Non-native Species in the UK Overseas Territories - Gap Analysis of Biosecurity Capacity. Sand Hutton, UK: Animal and Plant Health Agency

Kier G, Kreft H, Lee TM, Jetz W, Ibisch PL, Nowicki C, ... Barthlott W (2009) A global assessment of endemism and species richness across island and mainland regions. PNAS 106:9322-9327.

Lenzner B, Latombe G, Capinha C, Bellard C, Courchamp F, Diagne C, Dullinger S, Golivets M, Irl SDH, Kühn I, Leung B, Liu C, Moser D, Roura-Pascual N, Seebens H, Turbelin A, Weigelt $P$, Essl $F(2020)$ What will the future bring for biological invasions on islands? An expert-based assessment. Front Ecol Evol 8:280.

Leroy B, Kramer A, Vaissière A-C, Diagne C (2021) invacost: INVACOST Database With Methods To Analyse Invasion Costs. R package version 0.3-4.

http://borisleroy.com/invacost/Readme.html

Leung B, Lodge DM, Finnoff D, Shogren JF, Lewis MA, Lamberti G (2002) An ounce of prevention or a pound of cure: bioeconomic risk analysis of invasive species. Proc Roy Soc B 269:2407-2413.

McKinney ML, Lockwood JL (1999) Biotic homogenization: A few winners replacing many losers in the next mass extinction. Trends Ecol Evol 14:450-453. 
Mavian C, Dulcey M, Munoz O, Salemi M, Vittor AY, Capua I (2019) Islands as Hotspots for Emerging Mosquito-Borne Viruses: A One-Health Perspective. Viruses 11:11

https://doi.org/10.3390/v11010011

Mittermeier RA, Robles Gil P, Hoffman M, Pilgrim J, Brooks T, Mittermeier CG, Lamoreux J, da Fonseca GAB (2005) Hotspots Revisited. Earth's Biologically Richest and Most Endangered Terrestrial Ecoregions. Conservation International.

Mwebaze P, MacLeod A, Tomlinson D, Barois H, Rijpma J (2010) Economic valuation of the influence of invasive alien specieson the economy of the Seychelles islands. Ecol Econ 69:2614-2623.

Myers N, Mittermeier R, Mittermeier C, da Fonseca GAB, Kent J (2000) Biodiversity hotspots for conservation priorities. Nature 403:853-858. https://doi.org/10.1038/35002501

Naylor R (1996) Invasions in agriculture: Assessing the cost of the golden apple snail in Asia. Ambio 25:443-448

Nunes PALD, van den Bergh JCJM (2001) Economic valuation of biodiversity: sense or nonsense? Ecol Econ 39:203-222.

Oppel S, Beaven B, Bolton M, Vickery JA, Bodey TW (2011) Eradication of invasive mammals on islands inhabited by humans and domestic animals. Cons Biol 25: 232-240.

Orth RJ, Carruthers TJB, Dennison WC, Duarte CM, Fourqurean JW, Heck KL, Hughes, AR, Kendrick GA, Kenworthy WJ, Olyarnik S, Short FT, Waycott M, Williams SL (2006) A global crisis for seagrass ecosystems. Bioscience 56:987-996

Parkes JP, Ramsey DSL, Macdonald N, Walker K (2010) Rapid eradication of feral pigs (Sus scrofa) from Santa Cruz Island, California. Biol Cons 143:634-641.

R Core Team (2020). R: A language and environment for statistical computing. $R$ Foundation for Statistical Computing, Vienna, Austria. URL https://www.R-project.org/.

Reaser JK, Meyerson LA, Cronk Q, De Poorter M, Eldrege LG, Green E, Kairo M, Latasi P, Mack RN, Mauremootoo J, O'Dowd D, Orapa W, Sastroutomo S, Saunders A, Shine C, Thrainsson S, Vaiutu L (2007) Ecological and socioeconomic impacts of invasive alien species in island ecosystems. Environ Cons 34:98-111.

Renault D, Leroy B, Manfrini E, Diagne C, Ballesteros-Meina L, Angulo E, Courchamp F Biological invasions in France: Alarming costs and even more alarming knowledge gaps. NeoBiota. In Press

Roberts M, Cresswell W ad Hanley N (2018) Prioritising invasive species control actions: Evaluating effectiveness, costs, willingness to pay and social acceptance. Ecol Econ 152:18. https://doi.org/10.1016/j.ecolecon.2018.05.027

Russell JC, Innes JG, Brown PH, Byrom AE (2015) Predator-Free New Zealand: Conservation Country. Bioscience 65:520-525. doi:10.1093/biosci/biv012

Russell JC, Meyer J-Y, Holmes ND, Pagad S (2017). Invasive alien species on islands: Impacts, distribution, interactions and management. Environ Cons 44:359-370. 
Samaniego-Herrera A, Aguirre-Muñoz A, Bedolla-Guzmán Y, Cárdenas-Tapia A, FélixLizárraga M, Méndez-Sánchez F, Reina-Ponce O, Rojas-Mayoral E, Torres-García F (2018) Eradicating invasive rodents from wet and drytropical islands in Mexico. Oryx 52:559-570

Schultz M, Tyrrell TD, Ebenhard T (2016) The 2030 Agenda and Ecosystems - A discussion paper on the links between the Aichi Biodiversity Targets and the Sustainable Development Goals. SwedBio at Stockholm Resilience Centre, Stockholm, Sweden.

Seebens H, Blackburn TM, Dyer EE, Genovesi P, Hulme PE, Jeschke JM, Pagad S, Pyšek P, Winter M, Arianoutsou M, Bacher S, Blasius B, Brundu G, Capinha C, Celesti-Grapow L, Dawson W, Dullinger S, Fuentes N, Jäger H, Kartesz J, Kenis M, Kreft H, Kühn I, Lenzner B, Liebhold A, Mosena A, Moser D, Nishino M, Pearman D, Pergl J, Rabitsch W, RojasSandoval J, Roques A, Rorke S, Rossinelli S, Roy HE, Scalera R, Schindler S, Štajerová K, Tokarska-Guzik B, van Kleunen M, Walker K, Weigelt P, Yamanaka T, Essl F (2017) No saturation in the accumulation of alien species worldwide. Nature Communications 8:14435. doi:https://doi.org/10.1038/ncomms 14435

Sieber I, Borges P, Burkhard B (2018) Hotspots of biodiversity and ecosystem services: the Outermost Regions and Overseas Countries and Territories of the European Union. One Ecosystem 3:e24719.https://doi.org/10.3897/oneeco.3.e24719

Simberloff D, Martin J-L, Genovesi P, Maris V, Wardle DA, Aronson J, Courchamp F, Galil B, Garcia-Berthou E, Pascal M, Pysek P, Sousa R, Tabacchi E, Vila M (2013) Impacts of biological invasions - what's what and the way forward. Trends Ecol Evol 28:58-66.

Soubeyran Y, Meyer J-Y, Lebouvier M, De Thoisy B, Lavergne C, Urtizberea F, Kirchner, F (2015) Dealing with invasive alien species in the French overseas territories: results and benefits of a 7-year Initiative. Biol Inv 17:545-554.

Takahara T, Minamoto T, Doi H (2013) Using Environmental DNA to Estimate the Distribution of an Invasive Fish Species in Ponds. PLoS ONE 8: e56584.

https://doi.org/10.1371/journal.pone.0056584

Timmins SM, Braithwaite H (2002) Early detection of invasive weeds on islands. In: Turning the Tide: The Eradication of Invasive Species, eds. Veitch CR, Clout MN, pp. 311-318. Gland, Switzerland and Cambridge, UK: IUCN SSC Invasive Species Specialist Group, IUCN.

Towns DR, Broome KG (2003) From small Maria to massive Campbell: Forty years of rat eradications from New Zealand islands. NZ J Zool 30:377-398.

Turbelin AJ, Malamud BD, Francis RA (2017) Mapping the global state of invasive alien species: patterns of invasion and policy responses. Global Ecol Biogeog 26: 78-92.

United Nations (2017) Work of the Statistical Commission pertaining to the 2030 Agenda for Sustainable Development A/RES/71/313.

Vaas J, Driessen PPJ, Giezen M, vsn Laerhoven F, Wassen MJ (2017) Who's in charge here anyway? Polycentric governance configurations and the development of policy on invasive alien species in the semisovereign Caribbean. Ecol Soc 22:1

https://doi.org/10.5751/ES-09487-220401

Veitch CR, Clout MN, Towns DR (2011) Island invasives: eradication and management. Proceedings of the International Conference on Island Invasives IUCN, Gland, Switzerland. 
Veitch CR, Clout MN, Martin AR, Russell JC, West CJ (2019) Island invasives: scaling up to meet the challenge. Proceedings of the international conference on island invasives 2017. IUCN, Gland, Switzerland.

Watari Y, Komine H, Angulo E, Diagne C, Ballesteros-Mejia L, Courchamp F (2021) First synthesis of the economic costs of biological invasions in Japan. NeoBiota. In press.

Whittaker RJ, Fernández-Palacios JM (2007) Island Biogeography: Ecology, Evolution, and Conservation (Oxford Univ Press, Oxford), 2nd Ed.

Wood JR, Alcover JA, Blackburn TM, Bover P, Duncan RP, Hume JP, Louys J, Meijer HJM, Rando JC, Wilmshurst JM (2017) Island extinctions: processes, patterns, and potential forecosystem restoration Environmental Conservation. Cambridge University Press. doi:10.1017/S037689291700039X

van Kleunen M, Dawson W, Essl F, Pergl J, Winter M, Weber E, Kreft H, Weigelt P...Pysek $P$ (2015) Global exchange and accumulation of non-native plants. Nature 525:100-103. https://doi.org/10.1038/nature14910

Wallace RD, Bargeron CT, Reaser (2020) Enabling decisions that make a difference: guidance for improving access to and analysis of invasive species information. Biol Invasions 22:37-45.

World Bank Development Indicators https://databank.worldbank.org/source/worlddevelopment-indicators Accessed 15/12/2020

Zavaleta ES, Hobbs RJ, Mooney HA (2001) Viewing invasive species removal in a wholeecosystem context. Trends Ecol Evol 16:454-59.https://doi.org/10.1016/S0169$\underline{5347(01) 02194-2}$ 